\title{
Needs, effectiveness and limitations of the industrial policy of Serbia ${ }^{3}$
}

\author{
Article history: \\ Received 11 October 2012 \\ Sent for revision 22 February 2013 \\ Received in revised form 25 February 2013 \\ Accepted 25 February 2013 \\ Available online 15 April 2013
}

\begin{abstract}
Based on the position and the role of the industry that decisively affects the overall level of economic dynamics (GDP growth, employment rate, exports, competitiveness, innovation) this paper discusses some of the key factors which in an environment of deindustrialization of the Serbian economy call for the development and implementation of industrial policy, which is, again, the essential requirement for reindustrialization of the country. Building on the theoretical and methodological analysis of the most dominant contemporary concepts of industrial policy, the authors point to the need for setting and implementing an active, flexible and sophisticated industrial policy as an integral part of the socio-economic development of the country, since in this way the accumulation of structural disproportions can be achieved, as well as a more balanced presence on the world market. Current state of the industry, characterized by a relatively modest share in the GDP generation and overall employment, low productivity and competitiveness levels, outdated technologies, insufficient innovation and $R \& D$, is a result of the irresponsible attitude of the state towards this economic sector. Due to the presence of the existing economic, financial and industrial limitations, it is necessary for the state to define a consistent and sustainable industrial policy concept and to include all relevant stakeholders - ministries, employers, trade unions, research institutions and consumer organizations, in its implementation.
\end{abstract}

Keywords: industrial policy, innovation, $R \& D$, reindustrialization, structural change

\footnotetext{
${ }^{1}$ Prof. dr Vlastimir Leković, University of Kragujevac, Faculty of Economics, lekovic@kg.ac.rs

${ }^{2}$ Doc. Vladimir Mićić, University of Kragujevac, Faculty of Economics, micicv@kg.ac.rs

${ }^{3}$ This paper is a part of the research project no. 179015, funded by the Ministry of Education and Science of the Republic of Serbia
} 
Apstrakt: Na osnovu položaja i uloge industrije koja značajno utiče na opšti nivo privredne aktivnosti (rast BDP, zaposlenost, izvoz, konkurentnost, inovacije) u okruženju koje karakteriše deindustrijalizacija srpske privrede, u ovom radu se razmatra uticaj ključnih faktora na izradu i sprovođenje industrijske politike, koja je, u suštini uslov za reindustrijalizacije zemlje. Nadovezujući se na teorijske $i$ metodološke analize najdominantnijih savremenih koncepata industrijske politike, autori ukazuju na potrebu za uspostavljanje i sprovođenje aktivne, fleksibilne $i$ sofisticirane industrijske politike kao sastavnog dela društveno-ekonomskog razvoja zemlje, jer se na taj način može regulisati akumulacija strukturnih disproporcija, kao $i$ uravnoteženije prisustvo na svetskom tržištu. Sadašnje stanje industrije karakteriše relativno skromno učešće u kreiranju BDP i ukupne zaposlenosti, nizak nivo produktivnost $i$ konkurentnosti, zastarele tehnologije, kao i nedovoljan nivo inovacija, istraživanja i razvoja, što je rezultat neodgovornog odnosa države prema ovom sektoru privrede. Zbog postojećih ekonomskih, finansijskih i industrijskih ograničenja, neophodno je da država definiše dosledan i održiv koncept industrijske politike $i$ uključi u implementaciju sve relevantne faktore - vladu, poslodavce, sindikate, istraživačke institucije i organizacije potrošača.

Ključne reči: industrijska politika, inovacije, istraživanje i razvoj, reindustrijalizacija, strukturne promene

\section{Introduction}

Unsatisfactory results related to the functioning of the Serbian economy and low rates of economic growth, achieved during the last decades of the twentieth and at the beginning of the twenty-first century, point to the need of reviewing many of the key elements of the industrial policy and its impact on the development of the national economy. In doing so, we are faced with contradictory attitudes regarding the place and role of industrial policy - from challenging the role of the industrial policy to advocating the necessity for direct involvement of the state in order to accelerate economic growth and development. At the same time, the economic reality, not only in developing countries but also in developed ones, shows that industrial policy implementation results in numerous positive outputs, despite all efforts made by some economists to challenge it. In fact, economic reality confirmed that even in a market economy, implementation of industrial policy and coordination of economic actors' activities by the state affects the level of economic dynamics.

Analysis of the basic indicators of Serbian industry - which is faced with a number of problems such as low level of technological development and outdated production structure, low efficiency of utilization of production factors and the lack of competitiveness, indicates that deindustrialization actually represents the dominant feature. In accordance with the aforementioned facts, 
the aim of the research presented in this paper is to point to the gravity of the problem that deindustrialization of the country represents based on the concepts of dominant contemporary industrial policies, as well as to show that this problem cannot be successfully overcome without active participation of the state. It is emphasized that the initial hypothesis for kick-starting the activities and their successful realization, which should result in reindustrialization of the industry, rests upon the consistent and sustainable industrial policy. Initial hypothesis of this paper is that industrial production holds a key position in terms of dynamization of economic activities in the Serbian economy, GDP growth, job creation, rise in the standard of living, modernization of the economy and society. Therefore, it is necessary that the state defines a complete and consistent industrial policy, whose implementation will enable the achievement of these goals. The paper points out some of the key factors determining the need to design and implement such industrial policy that will result in implementation of the new development paradigm, based on research and development, new technologies, education, effective investments and integrative linking of all key partners involved in the production.

As far as the industrial policy is concerned, it is particularly important that the state defines its priorities and, above all, to support the development of innovative activities and technological knowledge as a key condition of productivity growth, which is a basic indicator of the efficiency and competitiveness of the economy. It is also important for industrial policy to be harmonized with other economic policies, because it is an essential prerequisite for its successful implementation. At the same time, due to the complexity of problems present in the industrial policy concept, on whose solution depends the performance of the economy as a whole, it is necessary to bear in mind that these are not "quick fix" activities, but rather a complex and long-term process of shaping the industrial and economic policy, as well as economic system as a whole.

\section{Contemporary Concept of Industrial Policy}

There are only few topics in terms of economic theory that are still largely disputed as are the issues of industrial policy and the role of the state in the economy. At the same time, the majority of scholars, as well as policy makers, firmly stand their ground on this subject, whether they are advocates of industrial policy or are strongly against it. However, the key question is - what kind of industrial policy the state should design and implement in order to make its economy more successful. It has been confirmed that, in modern economic environment, industrial activity makes one of the most important factors of economic development, which means that industrial policy is not in conflict with the paradigm of post-industrial development. Thus, in modern conditions, industrial policy is considered as one of the key components of success of the 
particular economy as a whole, as well as the success of its economic entities. In fact, in terms of the dynamic changes that characterize modern economy, where the production based on the intellectual activities is becoming more and more significant, not only that the modern industry did not lose its importance, rather it gained new, qualitatively different form. This is one of the reasons why it is necessary to point to the necessity of creating and implementing modern concept of industrial policy in Serbia as a way to overcome deindustrialization of the economy, stop the economic decline and stimulate economic growth and development, as well as achieve the modernization of the economy and society. Therefore, for the successful achievement of the above mentioned objectives, it is necessary that the competitiveness of industry and the economy as a whole, be regarded as one of the national objectives of strategic character, and that, in this context, high-tech products gain the significant role in the industry structure, which includes adequate support to the active and dynamic industrial policy.

Industrial policy is explained as an attempt by the state to stimulate economic growth through reallocation of resources. This includes different types of macroeconomic policies, activities, impacts and support to both new and the existing industries. It has been pointed out (Cimoli, Dosi \& Stiglitz, 2009) that it is particularly important to support emerging industries, development of science and technology and provide protection of intellectual property. This means that industrial policy is not neutral, because, if this were the case, this policy will, by no means, be industrial. At the same time, industrial policy is seen as a support and coordination provided by the state in order to increase the productivity and competitiveness of the economy as a whole, as well as individual industrial sectors. As far as the transitional economies are concerned, we are talking about two basic forms of industrial policy: the strategy of market development and market support strategies. In general, industrial policy should aim to support the market, but in countries in transition it should also be used as a means of establishing and developing markets. This means that the transition element of industrial policy targets the transformation of the economic system, as well as its restructuring, which represents the second phase of the transition process. The concept of industrial policy that will determine the state transition process depends on the size of the country and the degree of openness of the country's economy. In the times of modern structural changes, industrial policy objective is the establishment of a competitive industry, which should be a result of the establishment of a new type of specialization of industries based on the cutting edge technologies. Therefore, a key task of industrial policy is to create a contemporary, high-tech, competitive industrial environment that will introduce changes to production structure.

According to Porter (1990) the theory of competitive advantage seeks clarification on how the quality of production factors in the national economy could 
be increased, as well as their productivity in the new economic environment in which companies operate. Previous findings indicate that the role of government should be focused on creating an environment that would allow companies to achieve synergy in terms of their output, which is the main lever for achieving the competitive advantage of an economy as a whole. Although organizational and technologically innovative activities are the driving force of development, the role of the state in industrial policy is to continuously and consistently achieve the objectives of the effective implementation of institutional and organizational change and development in addition to overcoming market inefficiencies.

According to Porter (1990) the theory of competitive advantage seeks clarification on how the quality of production factors in the national economy could be increased, as well as their productivity in the new economic environment in which companies operate. Previous findings indicate that the role of government should be focused on creating an environment that would allow companies to achieve synergy in terms of their output, which is the main lever for achieving the competitive advantage of an economy as a whole. Although organizational and technologically innovative activities are the driving force of development, the role of the state in industrial policy is to continuously and consistently achieve the objectives of the effective implementation of institutional and organizational change and development in addition to overcoming market inefficiencies.

The experience of developed economies shows that a higher level of competitiveness of the national economy cannot be achieved without the implementation of industrial policy. The setting of industrial policy depends on the specific features of a complex institutional structure of a society and the structural characteristics of the economy. In this context, Rodrik (2004) pointed out that in developing countries it is difficult to find a prosperous economy that was not the result of industrial policy implementation, which is one of the basic instruments used to change the shape of the national industry and solve its structural problems. The concept of industrial policy involves government policy which steers economic activities in one country. At the same time, it is a great misconception to view this policy as a sole means of industrial development or as state policy that targets industry. Tatarkin and Romanova (2007) indicate that the conceptual ambiguity, inherent in the study of complex systems and therefore also in the industrial policy, actually consolidates principled position that the industrial policy represents an attempt by the state to foster economic growth and development.

There are numerous examples of countries in which the state, by implementing its industrial policy, had an active and positive role in terms of promoting economic development. It has been pointed out (Cimoli et al, 2009) that in countries such as Germany, Japan, the so-called. "Asian Tigers" and the like, 
succeeded in reviving their development thanks to the strategic steering of the economy, in which the active industrial policy played a key role. As far as the European Union is concerned, one may say that it has long tradition in terms of creation and implementation of industrial policy. The current industrial policy implemented by the European Union through a set of structural and other related instruments, is actually a response to the current processes of economic globalization in order to adequately prepare the companies and industries for the competition imposed by the global market. The main problems embedded in the industrial policy and important for the competitiveness of European industry can be grouped into four objectives: stimulating structural changes; creating favorable institutional environment for the development of companies, especially the development and growth of small and mediumsized companies; developing environment for entrepreneurial collaboration, and better use of innovation, research and technological development. It is important to mention the experience of China, where government incentives have improved exports and competitiveness in the global market. Also, the USA implemented industrial policy when there was an economic interest to do so. Dynamic technical and technological progress of this country is the result of the direct state support (development of Silicon Valley and the Internet as well as automotive industry bailout in 2009), although the term industrial policy is not used in the United States (Savić \& Mićić, 2011).

The efficiency of industrial policy implementation largely depends on the model of economic policy chosen by the policymakers. The liberal model gives emphasis to the free operation of the market mechanism, with minimal interference from the state, whilst the dirigistes allow active participation of the state in the economy, not only as a reformer, but also as an active subject the state as an entrepreneur and investor. In the framework of the mentioned models, the hard or vertical, i.e., soft or horizontal industrial policy is formed. The first involves stimulating actual production (subsidies and loans to producers, protectionist foreign trade policy, etc.), while the second model focuses on the creation of the general conditions for all industrial branches, including through promoting growth and competitiveness of national companies and providing support to investment projects that result in higher levels of efficiency of the private sector. Neoliberal policies, which are consistent with the recommendations of the Washington Consensus were implemented by many countries, however they proved unreliable. These countries implemented socalled soft industrial policies characterized by the reduction of state intervention and the liberalization of economic growth. Rodrik (2006a) points to the experience of Latin American countries which implemented the policies set by Washington Consensus, and where the rate of economic growth during the 1990s was much lower than the rates achieved in the 1980's. At the same time, remarkable export performance of economic leaders in Latin America - 
Brazil, Argentina and Chile - were largely the result of special support programmes that were implemented in these countries.

Based on the institutional approach, industrial policy is seen as completeness of the system as a whole, which enables the state to indirectly influence the industrial development. A common set of resources that are available to the state are: quotas, licensing, standardization, price regulation, changes in the ownership structure, antitrust measures and etc. Proponents of the institutional approach to industrial policy believe that, in its creation, it is not suitable to focus solely on the sectoral issues, given that, in an environment of dynamic economic and technological changes the emphasis is on the ability of the state and organizations to adapt to these constant changes in the environment and technology. Thus, sectoral priorities gradually lose their importance.

The opinion that it is necessary to abandon the traditional (sectoral) concept of industrial policy, as well as sectoral priorities, is present in literature (Mićić \& Zeremski, 2011), since sectoral priorities are impossible to predict and determine in the conditions of growing uncertainty. Factors such as human capital and creating incentives for hiring highly productive workforce come to the forefront. The essential role of the state should be the formation of the institutional structure of the economy focused on creating the conditions necessary for the implementation of technological and sectoral restructuring. The task of the state is to employ the industrial policy in order to create an institutional environment that will be favorable for continuous development of innovation and new technologies, as well as their practical implementation in various spheres of life. In this way, industrial policy allows for the development of new industries, which requires a strong, sophisticated and direct state support (Rodrik, 2010).

Industrial policy, as a strategy initiated and shaped by the state, includes a set of mechanisms through which, with a balanced combination of horizontal and vertical instruments, policies are implemented and the activities of economic actors coordinated. This influences the level of industrial dynamics. Industrial policy, which is designed to be compatible with other economic goals of society, is focused on the implementation of specific programs that should, thanks to the industrial growth and better economic performance, facilitate overall economic growth, full employment, macroeconomic stability, favorable balance of payments and overall growth of social and personal well-being. Therefore, in order to create and implement complex goals of industrial policy it is necessary to mobilize a large number of organizations and institutions, carriers of the economic and development policies of the country, in order to achieve successful consistency regarding the objectives of industrial policy and instruments and measures of economic policy. This approach is an essential prerequisite for the creation of appropriate instruments and measures 
of industrial policy, which determines the level of efficiency of the industry as well as the dynamics of its growth and development .

The state, through its industrial policy, shapes appropriate measures, both those that are part of an overall strategy and the provisional ones applied in the industrial sector in order to achieve specific goals of particular industrial branches. Due to the complexity of objectives and instruments and measures applied, it is often difficult to determine the boundary between industrial policy and other areas of economic policy. In this sense it has been indicated (Atkinson, Baker \& Milward, 1996) that the economic policy at the same time represents industrial policy, given that the measures adopted by the government in terms of the economic policy (changes in interest rates, tax policy, foreign economic policy, public procurement, research and development, etc.) influence the level of investment, affect the innovation and application of new technologies, which is directly reflected on the state of the industry, i.e. on industrial policy. In fact, in recent times, developed countries have been paying special attention to stimulating the development of high-tech sectors, where advanced technologies are used. This policy implies the use of tax regulations and government funds for stimulating scientific research and development activities ( $R \& D$ ) and interventions on the financial markets in order to direct investment funds to the sector stimulation and market interventions for the purpose of facilitating the formation of mergers, i.e. sufficiently large firms suitable for economies of scale.

Considering the complexity and ambiguity of industrial policy issues, a systematic approach is required in order to come to their objective and more comprehensive understanding. Thanks to such approach we arrive at the conclusion that the state is required not only to support the economic entities, but also to establish priorities in the realization of industrial potentials and structural changes, at the same time bearing in mind specific features of the economic development of a country and stimulating favorable institutional environment. While developing industrial policy based on a systematic approach, it is necessary to focus on consistency in terms of requirements analysis set out in other aspects of state policy, as well as the requirements for design of the objectives, principles, forms and methods of implementation of industrial policy. Kornai (2002) indicates that, changes that can be initiated and carried out with the help of the state or evolutionary realized are identified based on systematic paradigm. In line with this approach, the economy of the country is viewed as a system, where the mutual interaction of socioeconomic subsystems of the meso-, micro- and nano- economic levels is achieved: sectors, territories, corporations, individuals, social groups and etc.

As discussed above, industrial policy as an integral part of the social development strategy based on a system of mutual relations between the state and municipal authorities, enterprises, scientific and social organizations, contrib- 
utes to establishment of structurally balanced, competitive industry, which allows for internal coordination of all components of a system. In this regard, it represents one of the key objectives of the state policy, which has some things in common with other sectors, but at the same time maintains the specific objectives and instruments of implementation.

\section{Research Methodology and Data Collection}

For the purpose of exploring the key aspects of the modern theoretical concepts of industrial policy, and based on the relevant theoretical positions on one of the most important factors of economic development, the analytical description method was applied as a most suitable one. The industrial development indicators in Serbia, its neighboring countries and the EU (average value of industrial development indicators from $27 \mathrm{EU}$ member states) were examined by using comparative analysis. In order to identify the causes and processes of deindustrialization of the Serbian economy, which points to the necessity of creating and implementing industrial policies as a condition for faster economic growth and development and modernization of the economy, the correlation of three basic indicators was used, namely: the growth rate of production, gross value added (GVA) and employment in the industry. Particular emphasis in the analysis is given to the way of increasing the productivity in the manufacturing sector, which indicates that deindustrialization factors identified in the developed countries are not typical of the Serbian economy. A comparative analysis of innovation and sophistication of business operations based on the European Innovation Scoreboard Composite Index and the OECD classification of industries by their technology intensity, points to the crucial role of innovation in achieving the desired level of efficient and modern industry. Research and data analysis were carried out on the basis of the relevant sources of data provided by the Statistical Office of the Republic of Serbia, Eurostat and the World Economic Forum.

\section{The Need for Industrial Policy of Serbia}

Recommencing and intensifying of the economic transition after 2001 has not produced a strictly defined industrial policy of Serbia based on the production orientation and appropriate concept of development, which would be in function of the implementation of the industrial development strategy. Except for the purely declarative commitment to the necessity of structural change and structural policy setting, there is no document that clearly defines the goals, objectives and priorities of the industrial development in general, nor the industrial policy. Moreover, there is no clue on the manner of setting specific 
coordinated action programmes in the field of industrial policy. As a result, industrial policy is embodied in a series special programmes that are poorly interconnected, and are basically of a declarative character, thus in the majority of cases the necessary financial resources for their implementation are not provided. General ideas make the very core of these programmes, such as: development of export-oriented industries, protectionism and export support, development of innovation activities, the primacy of the market and market relations (minimization of state intervention, promotion of equal conditions of competition, open economy, etc.), primacy of the so-called "new economy" sector which, in essence, stands for the information technology sector and some service industries (tourism, education, transport).

The concepts that could somehow be considered as models of industrial policy in Serbia, are actually combination of efforts, which are primarily directed towards privatization and foreign investment through government incentives (subsidies and tax relief for foreign investors), and less oriented towards the development of the new small and medium-sized enterprises, the development of individual industrial enterprises and regional development (soft loans and bank guarantees - the Development Fund of the Republic of Serbia). Such attitude of the state towards industry and industrial policy, is primarily the result of such economic development model that is, again, the result of a dominant concept of transitional reforms based on liberalization, privatization and structural changes. In the period since 2001, the service industry has gained dominant role, which directly led to deindustrialization of the economy, while the industry (especially the manufacturing sector) has been practically devastated. The global economic crisis has only further emphasized the existing problems and deepened the extremely poor economic situation in the Serbian industry.

Current situation of the Serbian industry points to the necessity of defining and implementing an active, flexible and sophisticated industrial policy, which would be able to: (1) prevent further decline in industrial production and contribute to an increase in the rate of industrial growth in order to create conditions for more prominent participation of industry in generation of gross value added ( GVA) and job creation, (2) increase productivity (3) improve technological structure and increase the production volume of high-technology products, (4) encourage creativity and innovation, and (5) increase the level of competitiveness of the industry. This would create the conditions for the efficient development of industry, elimination of structural disproportions, more balanced performance on the global market and participation in the international division of labor.

(1) The average industrial growth rates achieved in the previous decade (particularly in the period of revival of industrial activities in the aftermath of the global economic crisis) and the average share of industry in GVA and total 
employment point to the lack of adequate industrial policy measures (Table $1)$.

Table 1 - Average industrial production growth rate, average share of industry in GVA and overall employment rate, 2001-2010, (in \%)

\begin{tabular}{|c|c|c|c|c|c|c|c|}
\hline & \multicolumn{5}{|c|}{ Production } & GVA & Employment \\
\hline & 2007 & 2008 & 2009 & 2010 & $2001 / 10$ & $2001 / 10$ & $2001 / 10$ \\
\hline EU-27 & 3.6 & -1.8 & -13.5 & 6.8 & 0.3 & 1 & 17.7 \\
\hline Slovenia & 4.7 & 1.6 & -17.6 & 6 & 1.9 & 25.2 & 26.2 \\
\hline Slovakia & 16.9 & 3.1 & -13.8 & 18.9 & 7.2 & 26.3 & 24.6 \\
\hline Poland & 9.5 & 2.0 & -3.6 & 10.8 & 5.9 & 28.4 & 21.2 \\
\hline Hungary & 8.0 & -1.0 & -17.4 & 10.3 & 3.9 & 25.8 & 22.2 \\
\hline Czech R. & 10.6 & -2.4 & -12.9 & 9.9 & 4.1 & 37.5 & 27.6 \\
\hline Romania & 10.1 & 2.6 & -6.4 & 5.5 & 2.4 & 25.4 & 20.2 \\
\hline Bulgaria & 9.5 & 0.4 & -18.2 & 2.2 & 4.0 & 24.1 & 22.7 \\
\hline Croatia & 5.0 & 0.7 & -8.9 & -1.5 & 2.2 & 18.3 & 19.2 \\
\hline Serbia & 4.1 & 1.4 & -12.6 & 2.5 & 0.6 & 21.7 & 25.5 \\
\hline
\end{tabular}

Source: European Commission (2012), Statistical Office of the Republic of Serbia (2012)

The overall effect of the extremely modest average growth rate of $0.6 \%$ in the period 2001-2010, is reflected in the fact that industrial production in Serbia in 2010 made about $45 \%$ of the 1990 level. In the analyzed period, the average share of industry in GVA was $21.7 \%(24.0 \%$ in 2001$)$, while its share in the GDP was $18.8 \%$ (22.2\% in 2001). At the same time, the average share of industrial workers in total employment was $25.5 \%$. However, this indicator also shows decreasing trend, since the share of industrial workers in total employment in 2001 was $33.5 \%$. Employment structure has changed significantly in favor of the persons employed in the service sector, which in this period increased from $46.9 \%$ to $58.5 \%$. The share of people employed in agriculture increased from $19.6 \%$ in 2001 to $22.2 \%$ in 2010 (Statistical Office of the Republic of Serbia, 2012).

(2) Productivity in the manufacturing industry sector (which produces the majority of tradable goods) is one of the main indicators of competitiveness and efficiency. Although there was no significant technological modernization of companies, i.e. industry, the growth of productivity in this sector has been recorded. However, productivity growth in industry is primarily the result of constant and numerous job cuts, rather than technical development and modernization or increase in the efficiency of production factors utilization, i.e. investments in innovation, technology and skilled staff, which cannot be sustainable in the long term period. Thus we come to the data (Table 2.) which shows that the rates of productivity growth are higher than the growth rate of production in the manufacturing industry sector. 
Leković, Mićić: Needs, effectiveness and limitations of the industrial policy of Serbia

Table 2 - The processing sector of the industry - the growth rates of production, employment and productivity (in \%)

\begin{tabular}{|l|c|c|c|c|c|c|c|c|c|c|}
\hline & 2002 & 2003 & 2004 & 2005 & 2006 & 2007 & 2008 & 2009 & 2010 & 2011 \\
\hline $\begin{array}{l}\text { Processing } \\
\text { industry }\end{array}$ & 2.8 & -4.4 & 8.3 & -1.0 & 4.5 & 4.6 & 1.1 & -16.1 & 3.9 & -0.5 \\
\hline Employment & -8.0 & -7.4 & -8.2 & -5.1 & -8.5 & -6.9 & -5.6 & -8.5 & -8.5 & -2.0 \\
\hline Productivity & 6.1 & 1.4 & 16.2 & 9.0 & 15.8 & 16.7 & 8.0 & -7.6 & 12.6 & $/$ \\
\hline
\end{tabular}

Source: Ministry of Finance of the Republic of Serbia (2011), Statistical Office of the Republic of Serbia (2012)

(3) According to the OECD Science, Technology and Industry Scoreboard (OECD, 2005), technology intensity, which is determined on the basis of technological sophistication of products, level of costs associated with $R$ \& $D$ and the number of scientific and technological workers, makes one of the key determinants of productivity growth and competitiveness. Concerning the technological intensity and its impact on productivity growth and participation in the creation of GVA, technological structure of Serbian industry is very unsatisfactory. The trend of changes in the structure of technology intensity is inadwquate. This confirms that the outdated technologies used in our industry are far behind modern technologies used in industrialized countries of the EU.

Table 3 - Technological structure of the Serbian industry, 2001-2010

\begin{tabular}{|l|c|c|c|c|c|c|c|c|c|c|}
\hline & 2001 & 2002 & 2003 & 2004 & 2005 & 2006 & 2007 & 2008 & 2009 & 2010 \\
\hline High technology & 0.8 & 0.6 & 1.6 & 0.7 & 2.7 & 2.3 & 1.4 & 1.2 & 0.9 & 1.0 \\
\hline $\begin{array}{l}\text { Medium -high } \\
\text { technology }\end{array}$ & 25.0 & 25.6 & 26.4 & 23.2 & 24.8 & 24.7 & 22.7 & 23.4 & 23.6 & 23.4 \\
\hline $\begin{array}{l}\text { Medium-low tech- } \\
\text { nology }\end{array}$ & 25.5 & 25.5 & 26.2 & 27.7 & 25.4 & 27.0 & 28.3 & 27.4 & 25.6 & 25.4 \\
\hline Low technology & 48.7 & 48.3 & 45.8 & 48.4 & 47.1 & 46.0 & 47.6 & 48.0 & 49.9 & 50.2 \\
\hline
\end{tabular}

Source: Authors'calculations

This difference in technological development at the beginning of the observed period amounted to about 5-6 generations of technology and thus far has not been significantly reduced. The data in Table 3, shows that the products of low and medium-low technology intensity have the largest share in production (and exports), while medium-high and high technology products have not increased their share in the structure of production and exports.

It can be concluded that in the area of technological development of the industry, generally accepted global trends and criteria in terms of technology intensity were neither considered nor accepted, which also indicates that a greater role of knowledge and highly-skilled staff, as well as comprehensive cooperation with scientific/research institutions was disregarded. The main 
cause of such lagging growth is the process of privatization and the unwillingness (or inability) of new owners to increase investment in the growth of technical sophistication and productivity of the privatized enterprises in the process of post-privatization restructuring. Technology intensity, by all means, influences the structure of exports (average share of industry in total exports in the analyzed period was about $94 \%$ ).

(4) Of particular concern is the fact that Serbia's economy is at the bottom of the list concerning the growth of innovation and business sophistication compared to its neighboring countries, which all strive to increase competitiveness (Table 4). In terms of innovation, Serbia is ranked 111th country, while in terms of technology readiness as measured by the Global Competitiveness Index (GCl) Serbia comes 58th. These data indicate that the low level of innovation is one of the main causes of very low productivity and poor competitiveness of the industry in Serbia.

Table 4 - Innovation factors

\begin{tabular}{|l|c|c|c|c|c|c|c|c|}
\hline \multirow{3}{*}{ Country } & \multicolumn{2}{|c|}{$\begin{array}{c}2012(144 \text { coun- } \\
\text { tries) }\end{array}$} & \multicolumn{2}{c|}{$\begin{array}{c}2011 \text { (142 coun- } \\
\text { tries) }\end{array}$} & \multicolumn{2}{c|}{$\begin{array}{c}2010 \text { (139 coun- } \\
\text { tries) }\end{array}$} & \multicolumn{2}{c|}{$\begin{array}{c}2009 \text { (133 coun- } \\
\text { tries) }\end{array}$} \\
\cline { 2 - 10 } & Rank & Results & Rank & Results & Rank & Results & Rank & Results \\
\hline Slovenia & 32 & 3.85 & 45 & 3.87 & 35 & 4.08 & 30 & 4.26 \\
\hline Montenegro & 60 & 3.31 & 59 & 3.62 & 56 & 3.67 & 68 & 3.56 \\
\hline Hungary & 37 & 3.61 & 52 & 3.75 & 51 & 3.17 & 61 & 3.67 \\
\hline Romania & 102 & 2.98 & 99 & 3.20 & 91 & 3.24 & 75 & 3.44 \\
\hline Bulgaria & 92 & 2.92 & 96 & 3.24 & 65 & 3.22 & 89 & 3.29 \\
\hline Croatia & 74 & 3.12 & 82 & 3.37 & 85 & 3.22 & 72 & 3.49 \\
\hline FYROM & 110 & 2.83 & 104 & 3.14 & 97 & 3.20 & 93 & 3.23 \\
\hline Albania & 123 & 2.63 & 102 & 3.18 & 107 & 3.09 & 121 & 2.90 \\
\hline Serbia & 111 & 2.81 & 118 & 2.99 & 107 & 3.04 & 94 & 3.21 \\
\hline B and H & 80 & 3.09 & 108 & 3.13 & 120 & 2.93 & 127 & 2.80 \\
\hline
\end{tabular}

Source: World Economic Forum (2009, 2010a, 2011 \& 2012)

Innovation is essential for an efficient and modern industry. According to the EU's composite index of innovation (Innovation Index) Serbia is ranked 29th out of $34 \mathrm{EU}$ countries whose capabilities are measured by this index. According to the mentioned index, Serbia belongs to the group of countries characterized by moderate innovations with a below average innovation performance (Table 5). In line with our commitment to the policy of structural redesign of the industry which should result in a creation of competitive industry, it is necessary to make innovation policy an essential element of the industrial policy in order to be able to form a new core technology. 
Leković, Mićić: Needs, effectiveness and limitations of the industrial policy of Serbia

Table 5 - Summary Innovation Index (SII)

\begin{tabular}{|l|l|l|l|l|l|}
\hline & 2007 & 2008 & 2009 & 2010 & 2011 \\
\hline EU-27 & 0.517 & 0.526 & 0.526 & 0.533 & 0.539 \\
\hline Bulgaria & 0.173 & 0.192 & 0.205 & 0.216 & 0.239 \\
\hline Czech R. & 0.397 & 0.404 & 0.386 & 0.400 & 0.436 \\
\hline Hungary & 0.314 & 0.316 & 0.320 & 0.333 & 0.352 \\
\hline Poland & 0.284 & 0.293 & 0.292 & 0.304 & 0.296 \\
\hline Romania & 0.226 & 0.242 & 0.265 & 0.259 & 0.263 \\
\hline Slovenia & 0.431 & 0.454 & 0.485 & 0.499 & 0.521 \\
\hline Slovakia & 0.295 & 0.309 & 0.307 & 0.322 & 0.305 \\
\hline Croatia & 0.260 & 0.269 & 0.283 & 0.281 & 0.310 \\
\hline Serbia & 0.252 & 0.259 & 0.257 & 0.284 & 0.282 \\
\hline Macedonia & 0.225 & 0.224 & 0.237 & 0.252 & 0.252 \\
\hline
\end{tabular}

Source: European Commission (2012)

At the same time, according to the criterion referring to the degree of fulfillment of the Lisbon objectives, i.e. catching up with the innovation and knowledge-based economies, Serbia only slightly improved the overall level of competitiveness. Furthermore, according to the overall Lisbon Strategy Index and the value of subindex - Society and Innovation and R \& D, Serbia is far below the EU-27 average, while as far as the neighboring countries are concerned only Albania and Bosnia and Herzegovina have worse ranking (Table 6). Table 6 - The results of the Lisbon strategy - the Lisbon Strategy
Index (LSI) and sub-indices

\begin{tabular}{|l|c|c|c|c|c|c|}
\hline \multirow{2}{*}{ Country } & \multicolumn{3}{|c|}{2008} & \multicolumn{3}{|c|}{2010} \\
\cline { 2 - 7 } & LSI & $\begin{array}{c}\text { Information } \\
\text { society }\end{array}$ & $\begin{array}{c}\text { Innovation } \\
\text { and R\&D }\end{array}$ & LSI & $\begin{array}{c}\text { Information } \\
\text { society }\end{array}$ & $\begin{array}{c}\text { Innovation } \\
\text { and R\&D }\end{array}$ \\
\hline EU-27 & 4.73 & 4.53 & 4.18 & 4.81 & 4.73 & 4.23 \\
\hline Slovenia & 4.58 & 4.71 & 4.12 & 4.79 & 4.84 & 4.28 \\
\hline Montenegro & 3.96 & 3.27 & 3.15 & 4.19 & 3.95 & 3.32 \\
\hline Hungary & 4.18 & 3.86 & 3.76 & 4.28 & 4.12 & 3.79 \\
\hline Romania & 3.84 & 3.70 & 3.30 & 3.96 & 3.48 & 3.37 \\
\hline Bulgaria & 3.68 & 3.57 & 3.04 & 3.77 & 3.63 & 3.12 \\
\hline Croatia & 4.10 & 3.69 & 3.41 & 4.18 & 4.04 & 3.36 \\
\hline FYROM & 3.53 & 3.17 & 2.78 & 3.79 & 3.86 & 2.93 \\
\hline Albania & 3.12 & 2.70 & 2.37 & 3.47 & 3.13 & 2.52 \\
\hline Serbia & 3.44 & 3.20 & 3.00 & 3.51 & 3.29 & 2.95 \\
\hline B and H & 3.12 & 2.83 & 2.43 & 3.07 & 2.86 & 2.54 \\
\hline
\end{tabular}

Source: World Economic Forum (2008 \&2010b)

The value of the Information Society sub-index indicates the extent to which Serbian industry utilized information and communication technology (ICT) for knowledge sharing and productivity improvement. Innovation in products and processes is crucial, especially for a country that lags behind. According to 
sub-index Innovation and $\mathrm{R} \& \mathrm{D}$, which is an indicator of the quality of scientific research institutions and the level of their cooperation with the industry, Serbia is among the countries that have the poorest ranking (concerning the observed countries).

(5) A large number of non-competitiveness factors, i.e. indicators, point to insufficient willingness of both industry and economy as a whole to move to a higher stage of development. Despite the implementation of certain reforms, Serbia is still far from the desired position and potential. The conducted analysis, as well as the conclusions indicate that the economic system is incomplete and rigid, which represents a constraint on competitive performance of enterprises in the world market. It is evident that the unsatisfactory and low competitiveness of the industry is one of the complex and structural problems. The cause of the low competitiveness, for the most part, is rooted in a passive attitude toward the burning issue of lack of competitiveness and the expectation that the problem will sort itself out. There is no clear strategy to increase the competitiveness of industry and economy, therefore it is no wonder that the competition is constantly deteriorating and becoming worse.

Figure 1 - The growth rates of GDP and industrial production in Serbia in the period 2001-2011




Achieving a higher level of competitiveness of the national economy, especially industry, is a national strategic objective. However, it is not possible to achieve this objective without the support of an active and dynamic industrial policy, as well as economic policy, which will stimulate modernization of industry, including increasing investment in knowledge, human capital and technological innovation. Status of the Serbian industry and the necessity of creating and implementing a consistent and comprehensive concept of industrial policy illustrate the growth rates of GDP and industrial production, which is one of most objective indicators of the overall economic activity results in Serbia in the period 2001-2011. Based on the indicators of movement in GDP and industrial production during this period (Figure 1), it can be concluded that industrial production has a modest impact on GDP growth.

In addition to data that illustrate the movement in GDP growth rate and industrial production, the data on the participation of industry in GVA and GDP, as well as the share of factory workers in total employment is also significant. At the beginning of the analyzed period, i.e. in 2001, the share of industry in GDP was $22.2 \%$ (24\% in GVA), while in 2010 it fell to $18 \%$ in GDP $(20.9 \%$ in GVA). At the same time, as a result of deindustrialization of the country, the number of industrial workers in total employment in Serbia fell from 704,000 in 2001 to only 383,000 in 2010 , i.e. from $33.5 \%$ to $19.3 \%$ concerning the share in total employment.

Table 7 - The growth rates of GDP and industrial production in Serbia in the period 2001-2011

\begin{tabular}{|c|c|c|c|c|c|c|c|c|c|c|}
\hline \multicolumn{7}{|c|}{ Industrija Srbije. \% učešć u stvaranju BDV. BDP i zaposlenosti } \\
\hline & 2001 & 2002 & 2003 & 2004 & 2005 & 2006 & 2007 & 2008 & 2009 & 2010 \\
\hline $\begin{array}{c}\text { Share of industry in GDP of } \\
\text { the economy (base-period } \\
\text { prices) }\end{array}$ & 24.0 & 23.9 & 22.2 & 21.0 & 21.9 & 21.8 & 22.1 & 20.5 & 18.8 & 20.9 \\
\hline $\begin{array}{c}\text { Share of industry in GDP of } \\
\text { the economy (base-period } \\
\text { prices) }\end{array}$ & 22.2 & 21.3 & 19.1 & 17.8 & 18.4 & 18.6 & 18.7 & 17.5 & 16.2 & 18.0 \\
\hline $\begin{array}{c}\text { No. of industrial workers } \\
\text { (in thousands) }\end{array}$ & 704 & 648 & 605 & 526 & 536 & 493 & 460 & 438 & 411 & 383 \\
\hline Share in total employment & 33.5 & 31.4 & 29.6 & 27.4 & 25.9 & 24.4 & 23.4 & 19.9 & 19.9 & 19.3 \\
\hline
\end{tabular}

Source: Statistical Office of the Republic of Serbia (2012)

The unsatisfactory state in the Serbian industry, as a result of a series of problems that this sector has been facing for a long time, is the result of the low efficiency of the basic factors of production, inadequate and outdated manufacturing equipment, lack of working capital, lack of adequate credit lines, and etc. In order to be able to effectively solve these problems it is necessary that, in theoretical and methodological terms, the concept of a con- 
sistent and sustainable industrial policy be defined, as well as specific organizational and management mechanism responsible for its implementation. Namely, with a clear formulation of the industrial policy, which will be focused on creating the conditions for industrial development based on advanced technology, it is necessary to have appropriate strategy for its implementation, with clearly defined priorities of overall industrial development and not only certain regions or territories. Serbia cannot improve efficiency, raise productivity and achieve higher levels of competitiveness and economic development without appropriate approach to industrial policy and relevant strategy.

\section{Limitations and Capabilities of Industrial Policy}

Based on the analyzed indicators, which illustrate the magnitude of devastation of Serbian industry in the past ten years, the readiness of the state to approach the issues related to this important sector of the economy in a more organized and systematic way was more than welcomed. The fact that the Government of the Republic of Serbia adopted the Industrial Development Strategy and Policy 2011-2020 shows country's commitment to improve situation in this sector. The opinion that it is necessary that it is necessary to give the industrial policy of Serbia the same importance as that in the most developed industrial countries prevailed.

However, all available experiences in this matter on the global level were not taken into consideration in drafting of the Serbian industrial policy (Savić \& Bošković). Moreover, the realization of the objectives defined in this document will be conducted in an environment where a number of internal and external constraints is present. These constraints are the result of both demanding global socio-economic development and the internal weakness and unfortunatelly the country will be certainly faced with them in the near future. Nevertheless, it is clear that the mistakes of the past decade, when the reconstruction and development of the industry and increase in exports were disregarded, should not be repeated. Thus, we arrive at the following question - what are the real chances for the successful implementation of the new industrial policy?

One of the drawbacks of the adopted strategy concerning the industrial policy is that it is based on too many areas and sectors that are too extensive for the present capabilities, state of the industry and available resources. In order to improve efficiency, productivity, competitiveness and specialization and be truly commited to the creation of products that would become the main export products of Serbian industry, first of all in the short term period, it is necessary to focus on the les complex production levels, ie. the product groups and individual products of low and medium-low technology intensity. It is essential that 
in the mid-term and long-term period, industrial policy measures increase the share of those groups of products, which are the result of more complex processing and are of higher quality, i.e. technologically more intensive and more innovative. Thanks to the said features, these products will generate greater value added.

The scope of invested resources, the pace of investment and the level of their efficiency, especially when it comes to domestic resources, is one of the key issues of both industrial policy and industrial strategy. It would be desirable that gross domestic investment were higher, especially the current level of gross national savings, which is not sufficient for initiating a significant "investment wave" in Serbia (primarily concerning the products that require larger investments). This implies that the gross domestic savings must be much greater (and increase at a faster rate) compared to the estimated $7.5 \%$ in 2001 and 19\% in 2020 (Ministry of Economy and Regional Development, 2011).

The amount of available investments could be put at risk due to the current consumption level, i.e. because of the growing pressure on consumption and the level of public debt in the post-crisis period, which amounted to $46.5 \%$ in 2011 (Ministry of Finance and Economy of Serbia, 2012). The expectations that the budget deficit will be reduced to $1 \%$ by 2015 are unrealistic, especially if they continue to meet the tendencies related to satisfying the appetites of politicians or their unrealistic promises given in the pre-election period. Also, the current structure of public spending and inefficient public investments are also one of the limiting factors. A particular problem is the amount of foreign debt (23.5 billion euros in 2011), as well as the tendency to again turn to borrowing.

The limitation is reflected in the modest planned amount of funds, about $1 \%$ of GDP, which would be allocated for the implementation of industrial policy and reindustrialization. More precisely we are talking about sum of 300 million euros in 2011 and 520 million euros in 2020 (Ministry of Economy and Regional Development, 2011). In terms of the implementation of the industrial policy concept for the purpose of establishing new, especially large industrial enterprises, and creation of new jobs, as well as the conditions for the growth of industrial production and exports, which are the real needs of society and the economy, allocated and planned funds, are insufficient for achieving such ambitious plans.

One of the cornerstones of the implementation of the Industrial Development Strategy and Policy of Serbia is FDI (it isplanned to achieve annual inflow from these sources in the amount of 2.3 billion euros, of which some $40 \%$ would be invested in the industry). However, due to the global economic crisis, there was a rapid reduction of foreign investment at the global level. The estimations that the level of foreign investment in Serbia in 2007 will be 
reached by the end of 2012 (UNCTAD, 2010), can hardly be realized, given that the second wave of economic crisis hit in the second half of 2011. Significant increase in the inflow of foreign investments in Serbia, is also limited by the existence of the present high-risks concerning the investments in our country, which is caused primarily by the political instability and underdeveloped institutional infrastructure. Such situation is illustrated by the data on relatively modest inflow of foreign investment in the last three years - 1.3 billion euros in 2009, 0.8 billion in 2010, and 1.2 billion euros in 2011 (National Bank of Serbia, 2012). In order to facilitate a more efficient implementation of the strategy and post-crisis growth model and to achieve an annual inflow of FDI, especially Greenfield investments in the amount that exceedes 2 billion euros, it is necessary to significantly improve the business environment and to reduce all types of risk.

In order to achieve the projected GDP growth of $5.8 \%$, it is necessary to achieve an annual production growth rate of of $6.9 \%$, which would allow the increase in the export of goods of $14.2 \%$ per year, as well as the increase of share of export in GDP of 65\% (Ministry of Economy and Regional Development, 2011). These projections are ambitious, but unrealistic, given that there are so many redundant industrial products intended for export in the selected parts of the industry, especially if one takes into account the fact that in the past decade industry accounted for over $90 \%$ of exports. Moreover, it is essential that the industry improve its competitiveness, which requires serious effort and investments, bearing in mind that, according to the Global Competitiveness Index in 2012, Serbia is on the 95th place out of 144 countries (World Economic Forum, 2012).

It is undisputed that the driver and a key factor for sustainable economic development in the future can only be an effective and highly competitive industry. In order to achieve the mentioned goal, it is necessary to design and implement an active and sophisticated industrial policy. Such industrial policy must be given a high priority, in order to initiate and successfully complete the process of reindustrialization and provide support to the development of efficient, dynamic and sustainable industrial base, which is a motor of economic growth and sufficiently competitive in the international export market. The growth rate of industrial production in the coming years will be largely determined by the growth of trade in products, which means that industrial policy is primarily aimed at this segment of the industry.

In developed countries, industry is a key sector that determines national competitiveness, given that the industry creates new advanced technologies and increases productivity. Serbian industry is, in many ways, at the development crossroads, which means that it is necessary to accept and implement the concept of competitive advantage as the key issue of its long-term development and integration into the European and world markets. Serbian industry 
should leave behind the concept of creating a competitive advantage by lowering the price of natural resources and labor. It should turn to the new concept of competitiveness which means that the competitive advantage is gained and maintained on the basis of scientific knowledge, technological development and innovation, as key factos of productivity. Accepting such development concept is a prerequisite for increasing competitiveness and reducing the technological and economic dependence on other countries. Increased competitiveness and development of industrial structure based on these factors, as well as the current state and the level of competitiveness, require that the competitive advantage should be created through strengthening of other economic and social factors and determinants of competitiveness. It goes without saying that this strategic requirement, which is necessary from the standpoint of sustainable growth and development, involves high capital investment and sufficient time for implementation.

In order to contribute to the successful reindustrialization of the economy, it is essential that the industrial policy should be focused on restructuring, redirecting the basic directions of development of industry and the development based on innovation and use of new technologies that would result in the creation of a "knowledge-based economy", development of new products, improvd business environment - especially concerning the small and mediumsized enterprises (SMEs), higher employment rate and establishment of a flexible labor market. However, it is unrealistic to expect that SMEs can become market leaders and exporters, primarily because of inadequate support measures and incentives for their development, which are in our country only given on short-term basis. It is essential that, in the process of reindustrialization, industrial policy is focused on the creation of large companies, which will be in charge of production, exports, employment and technological development, as well as become the leaders in these areas. This would enable the SMEs to become providers of complementary services and products for lage firms, and thus work more effectively. In addition, the industrial policy is expected to result in an increase in living standards, levelling-out of social disparities, eliminating regional disparities, improving energy efficiency and achieving environmental targets and objectives. In order to be successful, industrial policy must be flexible with realisticly achievable goals. In this respect, general goals should be avoided.

In terms of growing instability in the global economy and economic trends that have been brought about by the global economic crisis, the industrial policy is expected to be able to quickly and efficiently respond to unforeseen events and external influences that might affect the Serbian industry. High uncertainty can make a relatively optimal industrial policy flawed. The essence is that those who define and implement such policy identify and correct errors in case they occur. It is essential that industrial policy positively affects the development of other parts of the economy. Industrial policy should be based on 
a clear promotion of competitiveness, i.e. the growth of productivity and production in a sustainable manner, in order to ensure better and steadily improving standard of living and higher employment rate in the long run. In overcoming the problems faced by the industry, it is crucial to increase productivity, which is a prerequisite for successful internal development and international trade. Industrial policy, in addition to the direct contribution to the growth rate of industrial productivity, significantly influences the growth of agricultural productivity and service industry.

The state of Serbian industry, which was even in the period before the crisis characterized by long-term neglect, devastation, permanent and profound crisis, and reliance on the service sector, demands the application of a combined approach made of various types of industrial policy, as well as other relevant policies. Among other things, the effects of the global economic crisis have proven illusory position on the credibility and validity of the dominance of a single model of industrial policy, whether it is based on state intervention and the ability of the state to play the role of the market mechanism, or one that is based on the liberal concept of the supply-side economics (micro supply-side industrial policy).

This is part of a "good industrial and economic policy package". Sometimes, in terms of globalization and promotion of marketing principles, it can be considered that a selective industrial policy loses its purpose. According to the certain standpoints, it is assumed that regional and multilateral trade regulations (Rodrik, 2006b) or the laws on protection of intellectual property (Cimoli et al, 2009) prohibit the implementation of the industrial policy, particularly the selective one. However, in the framework of the multilateral trade regime established on the principles of the World Trade Organization (WTO), as well as the scope of intellectual property, there is a room for implementation of industrial policy in line with certain rules and only for a limited period of time.

As far as Serbia is concerned, moderate pro-active role of the state can give results only in the forthcoming period when the markets start to function properly and when the rules of market competition are established and the effects of the global economic crises are overcome. In this respect we primarily point to the necessity of creating industrial policy that will be characterized by certain selective and structural features, in addition to the dominant horizontal ones. The inflexible and incompleate market is unable to generate the appropriate conditions for structural change and industrial growth by itself, therefore, it necessary that the state should support the creation of such an industrial structure and business environment that would boost production, exports and employment.

Industrial policy, which is designed to be compatible with other economic goals of society, must be focused on the implementation of specific programs that should, thanks to industrial growth and better economic performance, 
facilitate overall economic growth, full employment, macroeconomic stability, favorable balance of payments and overall improvement of the social and personal well-being. In order to create and implement the complex goals of industrial policy, it is necessary to mobilize a large number of organizations and institutions and creators of economic development policy of the country to achieve successful compliance between the objectives of industrial policy on the one hand the instruments and measures of economic policy on the other. Industrial policy goals must be balanced with specific objectives, taking into account the consequences that they might have for the industry. Therefore, appropriate coordination is required in order to achieve dynamic interaction and synergy between all policy areas, including foreign exchange policy, monetary and fiscal policy, investment policy, income distribution policy, labor market management policy, as well as technology policy, trade policy, competition policy, policy for development of science and education, public procurement policy, FDI policy, policy on intellectual property rights and other relevant policies. This approach is an essential prerequisite for the creation of appropriate instruments and measures of industrial policy, which determines the level of industry efficiency and the dynamics of its growth and development.

Undoubtedly, in addition to technology policy, industrial policy is one of the most important levers that are used to influence and stimulate technological growth and development and enhance competitiveness. By studying the industrial revolutions, economic historians show that the progress of technological knowledge makes the crucial factor for improvement and dynamic development of the industry. Technological knowledge does not come out of nowhere, but is the result of investing in human resources and equipment. In this regard, it is necessary to mobilize financial resources in order to invest in mentioned areas and transfer the obtained results to industry (Cimoli et al, 2009). This is the key to success of reindustrialization policy as a prerequisite for a more dynamic growth and development of both the economy and the society.

Each "great transformation", as well as (re)industrialization implies a continuous process of accumulation of knowledge and skills, both at the individual level and at the level of an organization. A key component of such ability is developed based on formal education and acquired skills ("human capital"). Of course, building of organizations is one of the most difficult tasks of industrial development policy. The idea that corporations such as "Toyota", "Samsung", "Dad" or "Embraer", can emerge as leaders thanks only to the "magic of the market" is a fairy tale, which only a few can believe in today (Cimoli et al, 2009).

Among other things, it is essential for the successful industrial policy to be based on sophisticated cooperation of private businesses and the makers of industrial policy, since businesses know better than the state in which direc- 
tion industrial policy should be developed. However, the state is the one who has available mechanisms and resources to facilitate the achievement of the selected target (Savić \& Bošković, 2011). These points to the need to abandon the concept of autarchic development of the industry and to accept the concept of joint action of the entrepreneurs and the state, in terms of creating new concept of functioning, based on the application of advanced scientific knowledge and technological innovation.

This implies that defining of the policy framework, as well as the implementation of the industrial policy, requires close cooperation of all institutions and stakeholders (employers, trade unions, academic institutions, nongovernmental organizations, consumer associations, etc.). It is particularly important for the employers and entrepreneurs to realize that they can not be passive, rather they must ask themselves what is it that they can do in their companies to increase their level of competitiveness. They must start from accepting the concept of competitive advantage and then move to making improvements in the areas such as infrastructure, human resources, leadership and management, clustering, organizational development, establishing business networks in the country and abroad, sophistication of production processes, high quality and technological innovation of products, cooperation with educational and research institutions, improving corporate image, communication with customers and consumers, as well as other economic entities and institutions. The passive role of the businesses cannot be justified, as well as the attitude that it is only the state who is responsible for the structural changes, improvement of competitiveness and increase in exports (Mićic \& Zeremski, 2011). At the same time, measures of state intervention, implemented within the framework of industrial policy, need to be of limited duration, that is, to cause as little distortion as possible in terms of the market mechanism (Jakopin, 2012).

One of the features of industrial policy should be the support to organizations and industrial clusters, as the drivers of the future competitiveness of the economy, which, according to Porter (1990), represent a group of geographically-related companies and organizations. Strong companies are the very essence of clusters, including those in similar industries with already established market position. In this respect, a very significant interconnectedness of businesses, government and science is achieved, which usually results in the formation of strategic bodies that are competent to carry out necessary coordination. Also, it important to achieve interconnectedness between all the participants in the process, i.e. producers of goods and service providers, as well as those engaged in innovation activities, both in horizontal and vertical terms. An important advantage of cluster industrial policy is manifested through greater opportunities to better understand strengths and weaknesses of industrial development and in this way strengthens the partnership dialogue between the territorial administration and business, which results in a greater 
diversification of the economy. Advantages that the businesses have are manifested through more efficient use of human resources and infrastructure in the particular territory, as well as the utilization of recommendations provided by the scientific centers, thanks to which costs are being lowered and better performance in emerging markets provided.

Objectively speaking, only the measures of an active and sophisticated industrial policy can drive the reindustrialization of the country. This points to the need of creating an active and sophisticated industrial policy of Serbia. There is no doubt that the lessons learned and experiences of other countries can serve as a valuable starting point for the formulation of the key aspects and different ways of industrial policy implementation, as well as the successful establishment of the necessary institutions. In creating the own model of industrial policy, it is necessary to take into account some elements of industrial policy of the EU, which are defined in the strategy "Europe 2020". Experiences of the new member states indicate that the accession process and full integration into the EU imply the convergence of national industrial policy related to the common industrial policy of the European Union in accordance with the business environment and industrial structures of the EU (Mićić, 2009).

\section{Conclusions}

The concepts related to reforming the governance mechanisms and property relations in Serbian industry, which usually stand for implementation of institutional reforms aimed at downsizing of natural monopolies, liberalization of the market and privatization and commercialization of the existing manufacturing enterprises, did not have satisfactory results. Quite opposite, the reform processes resulted in devastation of the industry, which has significantly reduced its participation in the GDP generation and employment. Moreover, inadequate technical and technological structure is not able to provide a higher level of competitiveness, which according to the Global Competitiveness Index, put Serbia nearly at the bottom of the list of countries in our region. Therefore, this paper highlights the importance of creating and implementing the industrial policy, as well as its necessity for starting a new cycle that would result in dynamic growth and development and modernization of the economy and society. At the same time, successfully created and implemented industrial policy would offer a real possibility to achieve economic growth and financial stability, level out the balance of payments and more effectively solve the problem of employment, as well as improve standard of living. In this context, it is necessary to put emphasis on improving the capacity of economic entities and the state, in terms of successful adaptation to the changes in the environment and the introduction of new technologies. The state is expected to focus on creating an institutional environment that will be favorable for the 
creation of the conditions necessary for initiation and implementation of technological change, in order to generate innovation and advanced technologies and apply them in various spheres.

A mechanism necessary for the successful implementation of industrial policy is a set of legal, economic, financial, organizational and other measures used to support the creation of a competitive industry and to ensure its effective functioning. Activities related to implementation of industrial policy, which is aimed at forming competitive, high-performance industries, must result in more efficient production and better quality of life, as well as contribute to establishing a platform for solving the related issues in the most efficient way in the future.

Nowadays, when the structural problems of the domestic industry are apparently manifested and when it is clear that these problems will not be easily solved in the future, the state assumes the responsibility for the formation of basic economic and financial macroproportions to address structural problems. At the same time, structural imbalances are typical of the agents of innovation processeses from the point of the relationship between the large, medium-sized and small companies involved in innovation, which is one of the unfavorable forms of structural discrepancies. This situation is logical, since in the last couple of decades there were no serious structural changes in the economy. The significance and presence of the relevant issues related to industry and industrial policy indicate that this topic will undoubtedly be the subject of future studies, in order to explore the key issues in this economic sector in a scientific and methodological manner.

\section{References}

Atkinson, B., Baker, R., \& Milward, B. (1996). Economic policy. London-New York, itd.: Macmillan Publishing.

Cimoli, M., Dosi, G., \& Stiglitz, E.J. (2009). The Political Economy of Capabilities Accumulation: The Past and Future of Policies for Industrial Development, Industrial Policy and Development - The Political Economy of Capabilities Accumulation. New York: Oxford University Press.

-European Commission. (2012). European Innovation Scoreboard 2011- Enterprise and Industry. Belgium.

-Ministry of Finance of the Republic of Serbia. (2011). Development report 2010.

Jakopin, E. (2012). Postkrizna realokacija faktora rasta. Ekonomski horizonti, 14(2), 77-87. Retrieved from http://scindeks.ceon.rs/article.aspx?artid=1450863X1202077J0 doi:10.5937/ekonhor1202077J

Kornai, Я. (2002). Системная парадигма. Вопросы экономики, 4, 17-23.

Mićić, V., \& Zeremski, A.V. (2011). Deindustrijalizacija i reindustrijalizacija privrede Srbije. Industrija, 39(2), 51-68. Retrieved from http://scindeks.ceon.rs/article.aspx?artid=0350-03731102051M0 
Leković, Mićić: Needs, effectiveness and limitations of the industrial policy of Serbia

Mićić, V. (2009). Srbija i industrijska politika EU. Industrija, 37(1), 121-129. Retrieved from http://scindeks.ceon.rs/article.aspx?artid=0350-03730901121M0

-Ministry of Finance and Economy of Serbia. (2012). Javni dug Republike Srbije. Retrieved from http://mfp.gov.rs/UserFiles/File/tabele/2012\%20septembar/Tabela\%205\%20Jav ni\%20dug\%20Republike\%20Srbije.pdf 2012 Sep 2.

-National Bank of Serbia. (2012). Strane direktne investicije. Retrieved from http://www.nbs.rs/export/internet/latinica/80/inoekonomski odnosi/platni bilans/f di 2009 Jan 25.

-OECD. (2005). OECD Science, Technology and Industry Scoreboard 2005. (pp. 181184). Paris.

Porter, M.E. (1990). The competitive advantage of nations. London: Macmillan Press.

Rodrik, D. (2004). Industrial policies for the twenty-first century. Cambridge: Harvard University. Retrieved from http://www.hks.harvard.edu/fs/drodrik/UNIDOSep.pdf 2009 Sep 20.

Rodrik, D. (2006). Doomed to choose - Industrial policy as predicament. Cambridge: Harvard University. Retrieved from http://ksghome.harvard.edu/ drodrik/doomed.pdf 2012 Sep 1.

Rodrik, D. (2006). Industrial Development: Stvlized Facts and Policies. Cambridge: Harvard University. Retrieved from http://www.ksg.harvard.edu/rodrik 2009 Sep 1.

Rodrik, D. (2010). The Return of Industrial Policy. Project Syndicate. Retrieved from http://www.project-syndicate.org/commentary/rodrik42/English 2012 Sep 20.

Savić, L., \& Mićić, V. (2011). World economic crisis - Messages for the Future in Contemporary Issues in Economics. In: Bussiness and Management, EBM 2010.. Kragujevac, Serbia: Faculty of Economics.

Savić, L., \& Bošković, G. (2011). Uticaj svetske ekonomske krize na razvoj Srpske industrije. Industrija,39(4), 87-106. Retrieved from http://scindeks.ceon.rs/article.aspx?artid=0350-03731104087S0

-Statistical Office of the Republic of Serbia. (2012). Database. Belgrade.

-Ministry of Economy and Regional Development. (2011). Strategija i politika razvoja industrije Republike Srbije 2011-2020. Belgrade.

Tatarkin, A., \& Romanova, O. (2007). Промышленная политика и механизм ее реализации: системный подход.Экономика региона, 3, 19-31.

-UNCTAD. (2010). Global and Regional FDI Trends in 2009. Retrieved from http://www.unctad.org 2012 Sep 21.

-World Economic Forum. (2008). The Lisbon Review 2008.

-World Economic Forum. (2009). The Global Competitiveness Report 2009-2010.

-World Economic Forum. (2010). The Global Competitiveness Report 2010-2011.

-World Economic Forum. (2010). The Lisbon Review 2010.

-World Economic Forum. (2011). The Global Competitiveness Report 2011-2012.

-World Economic Forum. (2012). The Global Competitiveness Report 2012-2013. 